IdeAs

Idées d'Amériques

15 | 2020

Eau et gestion de l'eau dans les Amériques

\title{
Water in the Americas
}

Vincent Dubreuil and François-Michel Le Tourneau

Translator. Michael Hinchliffe

\section{CpenEdition}

\section{Journals}

Electronic version

URL: http://journals.openedition.org/ideas/8454

DOI: $10.4000 /$ ideas. 8454

ISSN: 1950-5701

\section{Publisher}

Institut des Amériques

Electronic reference

Vincent Dubreuil and François-Michel Le Tourneau, « Water in the Americas », IdeAs [Online], 15 | 2020 Online since 01 March 2020, connection on 24 September 2020. URL : http://journals.openedition.org/ ideas/8454; DOI : https://doi.org/10.4000/ideas.8454

This text was automatically generated on 24 September 2020.

\section{c) (i) $\ominus$}

IdeAs - Idées d'Amériques est mis à disposition selon les termes de la licence Creative Commons Attribution - Pas d'Utilisation Commerciale - Pas de Modification 4.0 International. 


\title{
Water in the Americas
}

\author{
Vincent Dubreuil and François-Michel Le Tourneau \\ Translation : Michael Hinchliffe
}

1 Water is a recurrent issue throughout the Americas. The context of global change renders it even more acute: the vagaries of rainfall in a changing climate, growing demand from ever increasing populations and the development of high consumption agricultural and industrial activities are making the equation between offer and demand more and more tricky to balance. Over the last two decades, extreme episodes of either drought or excess precipitation have become more frequent and led to successive "water crises", a situation that has attracted particular attention from researchers in social and environmental studies.

2 On the scale of the continent, the water resource is abundant. The Americas, for instance, account for $45.5 \%$ of cumulative worldwide river flow while they cover only $28.5 \%$ of the emerged landmass. There are several giant-sized rivers, such as the Mississippi, the Saint Lawrence, the Orinoco, not to mention the Amazon in a category of its own. The Northern regions, Canada in particular, have a very large number of lakes stocking a considerable share of the world's fresh water and are covered, temporarily or permanently, with snow and ice also representing a large part of the stock. However this abundance is characterized by highly uneven distribution, with deserts such as the Atacama or the Mojave and a large number of arid regions such as the Brazilian Nordeste or the south west of the United States, over and against very wet areas such as Amazonia or the Pacific seaboard of the Columbian Andes. Climate change has its effect on this distribution, but tends rather towards more frequent occurrences of drought where rainfall is already low than to any extension of areas of higher precipitation.

3 Unequal distribution is compounded by ways in which the water resource is exploited, from a highly predatory approach in Chile or in south western US states (Texas, Arizona, California) to a more community oriented one, as in the Andean or Nordeste oases. Water is indeed a much coveted resource, involved as it is in the development of a variety of economic activities: agriculture, whether irrigated or not, heavy industry and energy, both needing vast quantities, but also other industrial and domestic uses 
which are often situated in urban areas and therefore at increasing distances from the origin point. To supply such needs, huge systems divert the flow of rivers like the São Francisco or the Colorado toward arid areas hundreds of kilometers away, thereby merchandizing water as a transported element. It is of course of itself a vector for transport via waterways such as the Saint Lawrence seaway or the Parana-Paraguay canal. Thus water is central to ever increasing mobility in the Americas.

In America as elsewhere, water is linked to a form (or an absence) of social bond by virtue both of the range of activities it enables and of the different representations societies construct of the element water, together with the manner in which they integrate it into their development. In this respect, the history of relationships with water is an integral part of history generally. Since the inception of the Tennessee Valley Authority, countless projects have been set up to promote integrated water management. From canals through the Sonora Desert or Caatinga, to pharaonic dams on the Columbia River, the Xingu or the Iguazu, the model long prevalent was that of large scale constructions. The entire American continent numbers over 12,600 large dams $^{1}$; twelve of the largest reservoir lakes and half of the largest hydroelectric power stations in the world are to be found in the Americas. These projects acquire greater complexity when the rivers or aquifers concerned span national frontiers. The continental dimension of drainage areas implies negotiation and power politics between neighboring states, which opens an interesting window on stakes of major geopolitical importance.

5 All the stakes, conflicts and representations centered on water are to be found more locally and in exacerbation in the large American cities. Primarily this involves a dramatic degradation of the resource such that it has on occasion been written that a city has turned its back on its lake or river. A case in point is the extreme pollution of the Tietê in São Paulo which turned the river into a health hazard, but rivers have become open air sewers in many other cities, North America included, Los Angeles being an example. There is today, originating in the United States, a movement towards the reappropriation of riversides via voluntarist municipal "renewal" policies. However in many Latin American cities the situation remains problem-fraught not just on account of river pollution but also because of the way in which sections of the population, usually the poorest, are exposed to the risk of flooding. To study the diversity of situations with regard to water in cities throughout the Americas is to measure how the concepts of vulnerability and resilience are relevant on the scale of each territory.

It is the aim of the present issue of IdeAs on the theme of water in the Americas to look at this diversity of local and more overall situations: the environmental dimensions of the subject are fundamental in that they foreground physical aspects (the quantification of resources and their variations) together with their societal components, which means accounting explicitly for the interplay of the various territorial actors at their different levels. Hence geographical, but also historical, political, social, economic and cultural approaches all have a relevant contribution to make in a cogent study of this general theme.

7 Eight pieces have been selected by the editorial board. They cover the North (USA and Canada) and most South American countries (Brazil, Chile, Argentina, Peru and Bolivia). They also bring into play a diversity of milieus: urban (Buckeye, Curitiba, São Paulo, New Brunswick), rural (Nordeste, Atacama, Arizona), arid, tropical, cold. Most of 
the studies are concerned with the subject of conflicts together with the roles played by the various actors involved and deal with diverse categories of population, indigenous communities, farmers and, of course, city-dwellers with equally diverse standards and conditions of life. The vulnerability of each of these groups is clearly delineated and, while signaling the diversity of local situations, the authors also stress the recurrent problems to do with flooding and the access to water resources.

8 A first group of articles looks at the question of water generally, through the study of policies, institutions and programs put in place to deal with the resource and the conflicts engendered. Florence Larocque (Who Fought for Water and What Did they Fight For? A comparative Study of Water Conflicts in Latin America between 2000 and 2011) defines water as a unique and pluridimensional source of conflict in Argentina, Chile, Bolivia and Peru. The comparative nature of her study lets her trace how and why water conflicts developed and evolved differently from country to country. The study by Carolina Milhorance, Daniela Nogueira and Priscylla Mendes (Do Programa Um Milhão de Cisternas ao Água para Todos: divergências políticas e bricolagem institucional na promoção do acesso à água no Semiárido brasileiro) looks at the case of the Brazilian Nordeste, an arid or semi-arid region in which the "Million Cistern" and later the "Water for All" programs were set up. The authors describe the dynamics of alliances between social actors but also the conflicts between state bureaucracies and the difficulties in enacting public policies at local level. Dealing with an even more arid environment, that of the Atacama desert in Chile, Hugo Romero and Manuel Méndez (Territorios hidrosociales en las geografías altoandinas del Norte de Chile: modernización y conflictos en la región de Tarapacá) analyze the processes of production in the hydro-social territories of the Andean high plateau region of Tarapacá. They describe how conflicts involving traditional communities are linked to the introduction of western conceptions of space as a result of the process of modernization undertaken in the region (irrigation, mining). The last piece in this group, by Joan Cortinas and Franck Poupeau (Le champ des politiques hydriques dans l'Ouest étasunien: éléments d'interprétation des instruments d'action), sets out a study of water policies deployed against drought in the US West. They draw up a map of institutions present in the Colorado River Basin, producing a close statistical analysis and paying particular attention to water markets as an instrument the use of which varies from one state to another.

9 The second group of articles deals more specifically with urban areas where the concentration of people and activities raises more acutely the questions of risk, vulnerability and conflict. In their study, Guillaume Fortin, Charlotte Poirier, Francis Duhamel and Daniel Germain (Risques d'inondation et vulnérabilité: l'exemple du bassin versant de la rivière Kennebecasis, Nouveau-Brunswick, Canada) revisit concepts used by the social sciences (hazard, vulnerability, risk, perception) and their importance with respect to the adaptation of populations to climate change. They demonstrate how, at local, district level, any reduction in the risk of flooding necessitates a greater awareness in the population. Flood risk is also the subject of the piece by Gabriela Goudard and Francisco Mendonça (Eventos e episódios pluviais extremos: a configuração de riscos hidrometerológicos em Curitiba, Paraná - Brasil) in which the authors, by correlating physical elements (precipitation count) with vulnerability, show how Curitiba, a "model city" from the environmental point of view, has become a place exposed to risk from rainfall, a risk potentially aggravated by the lack of inter-communal cooperation on the scale of the agglomeration. Studying an even larger city, São Paulo, Neli Aparecida de Mello-Théry, Hervé Théry, Danilo Pereira Sato et Heloisa de Camargo 
Tozato (Vulnérabilité, risques et conflits liés à l'eau : la zone de protection environnementale de la plaine inondable du Tietê) describe vulnerabilities and risks in the River Tietê flood plain via an analysis of land use. They show how pressure from all directions (demographic, real estate interests, agricultural and industrial) combined with an entanglement of projects and policies in the environmentally protected zone have prevented the flood plain from functioning properly. The final article by Anne-Lise Boyer and Rebecca F.A. Bernat (De la luzerne aux masterplanned communities: enjeux de la gestion de l'eau sur un front d'urbanisation, le cas de Buckeye en Arizona) describes water management and its contradictions at municipal level in the US. The authors show how a laisser-faire approach at various levels of public authority (State and municipal) with regard to land use restricts the efficiency of mechanisms designed to regulate the exploitation of the water resource and the pressures it faces.

\section{NOTES}

1. International Commission on Large Dams (www.icold-cigb.org).

\section{AUTHORS}

\section{VINCENT DUBREUIL}

Vincent Dubreuil est Professeur à l'Université Rennes 2 et membre de l'UMR 6554 LETG (Littoral Environnement Télédétection Géomatique). Géographe climatologue, ses travaux portent sur les risques (sécheresse) et les changements climatiques en France et au Brésil de l'échelle locale (îlots de chaleur urbain) à l'échelle régionale (impact de la déforestation en Amazonie sur le climat) et utilisent de manière privilégiée les données de satellites. Il coordonne ou participe à plusieurs projets de recherches en collaboration avec le Brésil (CNRS, ANR, COFECUB, H2020, FAPESP...) et a été professeur invité dans les universités de Brasilia, Presidente Prudente, Londrina et Fortaleza.

\section{FRANÇOIS-MICHEL LE TOURNEAU}

François-Michel Le Tourneau est directeur de recherche au CNRS et directeur-adhoint de l'UMI iGLOBES (CNRS-ENS-Université d'Arizona). 